\title{
Biomass accumulation, photochemical efficiency of photosystem II, nutrient contents and nitrate reductase activity in young rosewood plants (Aniba rosaeodora Ducke) submitted to different $\mathrm{NO}_{3}^{-}: \mathrm{NH}_{4}^{+}$ratios
}

Denize Caranhas de Sousa BARRETO ${ }^{1}$, José Francisco de Carvalho GONÇALVES²*, Ulysses Moreira dos SANTOS JÚNIOR ${ }^{3}$, Andreia Varmes FERNANDES ${ }^{4}$, Adriana BARIANI 5 , Paulo de Tarso Barbosa SAMPAIO ${ }^{6}$

\section{ABSTRACT}

The rosewood (Aniba rosaeodora Ducke) is a native tree species of Amazon rainforest growing naturally in acidic forest soils with reduced redox potential. However, this species can also been found growing in forest gaps containing oxide soils. Variations in the forms of mineral nitrogen $\left(\mathrm{NO}_{3}^{-}\right.$or $\left.\mathrm{NH}_{4}^{+}\right)$may be predicted in these different edaphic conditions. Considering that possibility, an experiment was carried out to analyze the effects of different $\mathrm{NO}_{3}^{-}: \mathrm{NH}_{4}^{+}$ratios on the growth performance, mineral composition, chloroplastid pigment contents, photochemical efficiency photosystem II (PSII), and nitrate redutase activity (RN, E.C.1.6.6.1) on $A$. rosaeodora seedlings. Nine-month-old seedlings were grown in pots with a washed sand capacity of $7.5 \mathrm{~kg}$ and submitted to different $\mathrm{NO}_{3}^{-}: \mathrm{NH}_{4}^{+}$ratios $\left(\mathrm{T}_{1}=0: 100 \%, \mathrm{~T}_{2}=25: 75 \%, \mathrm{~T}_{3}=50: 50 \%, \mathrm{~T}_{4}=75: 25 \%\right.$, and $\left.\mathrm{T}_{5}=100: 0 \%\right)$. The lowest relative growth rate was observed when the $\mathrm{NO}_{3}: \mathrm{NH}_{4}^{+}$ratio was equal to $0: 100 \%$. In general, high concentrations of $\mathrm{NO}_{3}$ rather than $\mathrm{NH}_{4}^{+}$favored a greater nutrient accumulation in different parts of the plant. For the chloroplastid pigment, the highest $\mathrm{Chl} a, \mathrm{Chl} b, \mathrm{Chl}_{\text {tot }}, \mathrm{Chl} a / b$ and $\mathrm{Chl}_{\text {tot }} / \mathrm{C}_{\mathrm{x}+\mathrm{c}}$ contents were found in the treatment with 75:25\% of $\mathrm{NO}_{3}^{-}: \mathrm{NH}_{4}^{+}$, and for $\mathrm{Chl} b$ and $\mathrm{C}_{\mathrm{x}+\mathrm{c}}$ it was observed no difference. In addition, there was a higher photochemical efficiency of PSII (F /F $)$ when high $\mathrm{NO}_{3}{ }^{-}$concentrations were used. A linear and positive response for the nitrate reductase activity was recorded when the nitrate content increased on the culture substrate. Our results suggest that $A$. rosaeodora seedlings have a better growth performance when the $\mathrm{NO}_{3}{ }^{-}$concentrations in the culture substrate were higher than the $\mathrm{NH}_{4}^{+}$concentrations.

KEYWORDS: Chloroplastid pigments, Chlorophyll $a$ fluorescence, Tree species.

\section{Acúmulo de biomassa, eficiência fotoquímica do fotossistema II, conteúdo de nutrientes e atividade da redutase do nitrato em plantas jovens de pau- rosa (Aniba rosaeodora Ducke) submetidas a diferentes relações $\mathrm{NO}_{3}{ }^{-}: \mathrm{NH}_{4}^{+}$}

\begin{abstract}
RESUMO
O pau-rosa (Aniba rosaeodora Ducke) habita, naturalmente, solos florestais ácidos com potencial redox reduzido. No entanto, esta espécie tem sido encontrada também em clareiras que, teoricamente, apresentam solos mais oxidados. Nestas diferentes condições edáficas, pode-se prever variaçōes nas formas do nitrogênio mineral $\left(\mathrm{NO}_{3}^{-}\right.$ou $\left.\mathrm{NH}_{4}^{+}\right)$. Considerando essa possibilidade foi conduzido experimento com o objetivo de estudar os efeitos de diferentes relaçóes de $\mathrm{NO}_{3}^{-}: \mathrm{NH}_{4}^{+}$sobre o acúmulo de biomassa, a composição mineral, as concentrações de pigmentos cloroplastídicos, a eficiência fotoquímica do fotossistema II e a atividade da enzima redutase do nitrato (RN, E.C.1.6.6.1) em A. rosaeodora. Plantas jovens com nove meses foram cultivadas em vasos com capacidade para 7,5 kg e submetidas a diferentes relaçôes de $\mathrm{NO}_{3}{ }^{-} \mathrm{NH}_{4}^{+}\left(\mathrm{T}_{1}=0: 100 \%, \mathrm{~T}_{2}=25: 75 \%\right.$, $\mathrm{T}_{3}=50: 50 \%, \mathrm{~T}_{4}=75: 25 \%$ e $\left.\mathrm{T}_{5}=100: 0 \%\right)$. As menores taxas de acúmulo de biomassa foram observadas quando a relação das concentraçôes de $\mathrm{NO}_{3}^{-}: \mathrm{NH}_{4}^{+}$foi igual a $0: 100 \%$. De maneira geral, a maior concentração de $\mathrm{NO}_{3}^{-}$em relação a $\mathrm{NH}_{4}^{+}$ favoreceu maior acúmulo de nutrientes nas diferentes partes da planta. Para os teores de pigmentos cloroplastídicos, os maiores valores de $\mathrm{Chl} a, \mathrm{Chl}_{\text {tor }}, \mathrm{Chl} a / b$ e $\mathrm{Chl}_{\text {tot }}{ }_{\mathrm{x}+\mathrm{c}}$, foram encontrados no tratamento com 75:25\% de $\mathrm{NO}_{3}^{-}: \mathrm{NH}_{4}^{+}$, não ocorrendo diferença para os teores de $\mathrm{Chl} b \mathrm{e} \mathrm{C}_{\mathrm{x}+\mathrm{c}}$. Em relação a eficiência fotoquímica do fotossistema II $\left(\mathrm{F}_{\mathrm{v}} / \mathrm{F}_{\mathrm{m}}\right)$ maior eficiência também ocorreu quando predominou maior concentração de $\mathrm{NO}_{3}{ }^{-}$em relação ao $\mathrm{NH}_{4}^{+}$. Quanto a atividade da reductase do nitrato observou-se resposta linear e positiva para o incremento da concentração de nitrato no substrato de cultivo. Portanto, os resultados obtidos sugerem que as plantas jovens de $A$. rosaeodora apresentaram melhor desempenho quando as concentrações de $\mathrm{NO}_{3}{ }_{3}^{-}$no substrato de cultivo foram superiores as concentraçôes de $\mathrm{NH}_{4}^{+}$.
\end{abstract}

PALAVRAS-CHAVE: Pigmentos cloroplastídicos, Fluorescência da clorofila $a$, Espécie arbórea.

'Laboratório de Fisiologia e Bioquímica Vegetal, Instituto Nacional de Pesquisas.

2Instituto Nacional de Pesquisas da Amazônia. e-mail: jfc@inpa.gov.br

${ }^{3}$ Laboratório de Fisiologia e Bioquímica Vegetal, Instituto Nacional de Pesquisas - e-mail: santosjunior.ulysses@gmail.com *autor de correspondência

${ }^{4}$ Laboratório de Fisiologia e Bioquímica Vegetal, Instituto Nacional de Pesquisas. e-mail: varmes@inpa.gov.br;

${ }^{5}$ Laboratório de Fisiologia e Bioquímica Vegetal, Instituto Nacional de Pesquisas. e-mail: bariani@inpa.gov.br;

${ }^{6}$ Coordenação de Pesquisas em Silvicultura Tropical (INPA-CPST). e-mail: sampaio@inpa.gov.br 


\section{INTRODUCTION}

The Amazon rain forest is considered the richest and most complex biome in the world (In the forest, there are between 5,000,000 and 30,000,000 of different plants). However, the irrational use of its forest resources has been provoking the extinction of different plant species and/or vegetal communities. An example of this situation is the tree specie rosewood (Aniba rosaeodora Ducke), a plant with multiple uses whose principle economic value is associated with synthesis and the physical-chemical properties of its essential oils (Rosa et al., 1997; May \& Barata, 2004). Its trunk wood contains an essential oil rich in linalool (3,7-dimethyl1,6-octadien-3-ol), a chemical which can be transformed into a number of derivatives of value to the flavor, fragrance industry and aromatherapy formulations. Over the past decades, the intensive harvest and the high demand for the oil have threatened with extinction remaining $A$. rosaeodora trees (Clay et al., 2000). Although $A$. rosaeodora is an important species both ecologically and economically, studies concerning physiological and metabolism characteristics related to its response to primary factors (water, light, $\mathrm{CO}_{2}$ and nutrients) are still widely unknown (Gonçalves et al., 2005).

In tree species, carbon $(\mathrm{C})$ and nitrogen $(\mathrm{N})$ metabolisms are considered determinant factors for accumulation of biomass. (Lawlor, 2002). Thus, in all types of plantations, nitrate availability is essential for vegetal growth (Öhlund \& Näsholm, 2001; Xiaoxin et al., 2007). Plants absorb the nitrogen mineral from soil, principally in the forms of nitrate $\left(\mathrm{NO}_{3}^{-}\right)$and ammonium $\left(\mathrm{NH}_{4}^{+}\right)$available in the soil solution through the mineralization of organic material or through the application of chemical fertilizers (Lemos et al., 1999; David $\&$ Bert, 2005). The effect of nitrogen on the plant growth is well documented. According (Meyer et al., 2006) most environmental conditions that induce phenotypic plasticity in leaves involve variation in carbon and nitrogen economy. However, plants show differences in their qualitative as well as in their quantitative responses to the use of $\mathrm{N}$ depending on the particular physiological processes considered. For example, in photosynthesis, $\mathrm{N}$ is directly related to the quantity of irradiance intercepted and how efficiently it is used, due to its presence as a prosthetic group in chlorophyll and in proteins. This demonstrates a strict correlation with the metabolism of carbon (Majerowicz \& Kerbauy, 2002). It has been shown that the assimilation of carbon through photosynthesis is dependent on the activity of ribulose 1,5 bisphosphate carboxylase-oxygenase (Rubisco) that represents approximately $40 \%$ of the protein concentration in leaves. (Pimentel, 1998). With an increased availability of nitrogen, there is a proportional increase in the activity of Rubisco and, consequentially, in the assimilation of carbon, a fact that is reflected by the increase of vegetal biomass.
Of the different forms of nitrogen used by plants, $\mathrm{NO}_{3}^{-}$ is considered the principal source of inorganic nitrogen influencing the growth of plants (Kaiser \& Huber, 2001). In this sense, the differential cations and anions uptake is one of the determinant factors in the interaction between ions, either in the soil solution or in artificial systems (nutritive solutions). This differential uptake is immediately reflected in the alteration of the rhizosphere $\mathrm{pH}$, and consequently influencing the uptake of other mineral elements. In addition, the form of nitrogen absorbed by plants is affected by factors such as temperature, oxygen, and $\mathrm{pH}$ (Majerowicz \& Kerbauy, 2002). Close to $70 \%$ of the cations and anions absorbed by plants are represented by $\mathrm{NO}_{3}{ }^{-}$and $\mathrm{NH}_{4}^{+}$(Van Beusichem $e t$ al., 1988). A high $\mathrm{NO}_{3}^{-}$uptake implies in the increase of the rhizosphere $\mathrm{pH}$ and, conversely a high $\mathrm{NH}_{4}^{+}$uptake causes a decrease of the rhizosphere $\mathrm{pH}$ (Clark 1982).

The utilization of $\mathrm{NO}_{3}$ - by plants involves the reduction of nitrite $\left(\mathrm{NO}_{2}^{-}\right)$by nitrate reductase and subsequently reduction to $\mathrm{NH}_{4}^{+}$by nitrite reductase. Then, $\mathrm{NH}_{4}{ }^{+}$is incorporated into carbon compounds (amides and ureides) by the glutamine synthetase (GS; EC 6.3.1.2) - glutamate synthase (GOGAT; EC 1.4.1.13) pathway (Lemos et al. 1999, Viégas \& Silveira 2002). Despite the innumerous reports about mineral nitrogen uptake in trees, our knowledge on nitrogen assimilation in Amazon rainforest plants is still limited, particularly at biochemical level. A better understanding in the function of enzymes related to mineral nitrogen assimilation is crucial for the maintenance of tree nitrogen economy (Canton $e t$ al., 2005). Thus, a better understanding of the optimization of $\mathrm{NO}_{3}{ }^{-}: \mathrm{NH}_{4}{ }_{4}^{+}$ratio is very important in order to maximize the primary productivity of species and consequently the accumulation of biomass.

Therefore, considering the qualitative and quantitative variations in the forms of $\mathrm{N}$-mineral, and the natural presence of the $A$. rosaeodora in edaphic environments of low $\mathrm{pH}$ and high humidity (with high contents of ammonium in detriment to nitrate), it may be possible that $A$. rosaeodora responds better to $\mathrm{NH}_{4}^{+}$. Nevertheless, other scientific evidences demonstrate that $A$. rosaeodora plants can be found in forest gaps (Clay et al., 2000). In contrast to the closed forest, the soil in forest gaps are characterized by the high exposure to irradiance and elevate temperatures which may favor the conversion of $\mathrm{NH}_{4}^{+}$ to $\mathrm{NO}_{3}$ - Thus, the objective of this study was to investigate the effect of different $\mathrm{NO}_{3}^{-}: \mathrm{NH}_{4}^{+}$ratios on the accumulation of biomass, mineral nutrition, chloroplastid pigments contents, photochemical efficiency of PSII, and the activity of the nitrate reductase (RN; EC 1.6.6.1) in A. rosaeodora seedlings. 


\section{MATERIAL AND METHODS}

\section{STUDY AREA AND EXPERIMENT CONDITIONS}

This study was conducted in the experimental area of the V-8 Campus in the Instituto Nacional de Pesquisas da Amazônia (INPA) in Manaus-AM-Brasil (3º's, 5952'W), under semi-controlled conditions in a greenhouse with an average temperature of $26.7 \pm 4^{\circ} \mathrm{C}$. The experiment was carried out using nine-month-old Rosewood plants (Aniba rosaeodora Ducke), produced from seeds collected in the Adolpho Ducke forest reserve, and located at Km 26 of the AM-10, Manaus-Itacoatiara highway. Seeds were selected according to their uniformity, size and a healthy state. After disinfections in sodium hipochlorite solution, $1 \%$ sodium $(\mathrm{v} / \mathrm{v})$, for 10 minutes, seeds were washed in running water and then in distilled water. Afterwards, they were placed in plastic boxes filled with washed sand as substrate to germinate. After reaching a height of $10 \mathrm{~cm}$, the seedlings were transferred to black polyethylene bags containing a compost mixture and sand in a proportion of $2 / 1(\mathrm{w} / \mathrm{w})$, where they remained for a period of 30 days for acclimatation. Following this period, nine-month-old $A$. rosaeodora seedlings were submitted to five treatments prepared according to the Hoagland and Arnon (1950) solution, modified to contain different ratios of $\mathrm{NO}_{3}^{-}: \mathrm{NH}_{4}^{+}\left(\mathrm{T}_{1}=0: 100 \%, \mathrm{~T}_{2}=25: 75 \%, \mathrm{~T}_{3}=50: 50 \%, \mathrm{~T}_{4}=\right.$ $75: 25 \%$ and $\left.\mathrm{T}_{5}=100: 0 \%\right)$. For the experiment, $A$. rosaeodora seedlings were carefully removed from the polyethylene bags and transferred to vases with water in order to avoid any potential damage due to dehydration of the plant root system (particularly the thin roots). After that, seedlings showing a normal aerial and root development were selected for further experiments. Selected plants were transplanted to plastic vases with a capacity of $7.5 \mathrm{~kg}$, containing washed sand as substrate. Plants were irrigated with a nutritive solution containing $1 / 5$ of the concentration used in the five treatments and exposed during growth to about $1000 \mu \mathrm{mol} \mathrm{m} \mathrm{m}^{-2} \mathrm{~s}^{-1}$ obtained with fiberglass cover. The salts with the respective concentrations used in the solution preparation were: $\mathrm{KH}_{2} \mathrm{PO}_{4}, \mathrm{MgSO}_{4}$, $\mathrm{Ca}\left(\mathrm{NO}_{3}\right)_{2} .4 \mathrm{H}_{2} \mathrm{O},\left(\mathrm{NH}_{4}\right)_{2} \mathrm{SO}_{4}, \mathrm{KNO}_{3}, \mathrm{KCl}, \mathrm{CaCl}_{2}, \mathrm{NH}_{4} \mathrm{Cl}$, $\mathrm{CaSO}_{4} .2 \mathrm{H}_{2} \mathrm{O}, \mathrm{NH}_{4} \mathrm{NO}_{3}$ and $\mathrm{NaNO}_{3}$, with $0.5 ; 0.75 ; 0.5$; 2.25 ; $1.25 ; 1.25 ; 0.5 ; 0.575 ; 0.5 ; 1.15$; and $0.575 \mathrm{mmol} \mathrm{L}^{-1}$, respectively, and, the micronutrients, $\mathrm{H}_{3} \mathrm{BO}_{3}, \mathrm{MnCl}_{2} .4 \mathrm{H}_{2} \mathrm{O}$, $\mathrm{ZnSO}_{4} .7 \mathrm{H}_{2} \mathrm{O},\left(\mathrm{NH}_{4}\right)_{6} \mathrm{Mo}_{7} \mathrm{O}_{24} \cdot 4 \mathrm{H}_{2} \mathrm{O}, \mathrm{CuSO}_{4}$ and Fe-EDTA with 23.06 ; 6.29; 0.65 ; 0.05 ; 0.16 and $44.81 \mu \mathrm{mol} \mathrm{L}^{-1}$, respectively.

During the experiment, the solution $\mathrm{pH}$ in the substrate was monitored and adjusted daily to $\mathrm{pH} 6$, using $\mathrm{HCl}$ or $\mathrm{NaOH}$. Under each vase, a plastic support was placed in order to collect the excess of nutritive solution, which was returned to the substrate. In addition, the level of soil moisture was maintained by replacing daily the water lost with evapotranspiration. This procedure was made possible by weighing the vases at the beginning of the experiment and everyday during the experiment. Solutions were changed every six days for 120 days until the completion of the experiment. To determine the influence of different levels of $\mathrm{NO}_{3}^{-}: \mathrm{NH}_{4}^{+}$ ratios in seedlings of $A$. rosaeodora the following variables were measured: growth relative rate in biomass, nutrients content, concentration of chloroplastid pigments, photochemical efficiency of PSII and nitrate reductase activity (RN, EC 1.6.6.1).

\section{GROWTH ANALYSIS}

The growth of $A$. rosaeodora seedlings was monitored through determinations of biomass, by obtaining the relative growth rates of leaves, stems and roots, completed in two stages. The measurements were taken at an interval of four months, at the beginning and at the conclusion of the experiment. After 120 days of experiment, plants were collected, separated into leaf, stem and root, and dried in a stove at $70^{\circ} \mathrm{C}$ until a constant weight was observed (Böhm, 1979). The determination of relative growth rate of leaf mass (RGR-L), stem mass, (RGR-S), root mass (RGR-R) and total mass (RGR-Total) was obtained with the equations below, according to the methodology described by Bugbee (1996) and Davanso et al. (2002):

$$
\begin{aligned}
& \text { RGR-L }=\left(\log \mathrm{L}_{2}-\log \mathrm{L}_{1}\right) /\left(\mathrm{t}_{2}-\mathrm{t}_{1}\right) \\
& \text { RGR-S }=\left(\log \mathrm{S}_{2}-\log \mathrm{S}_{1}\right) /\left(\mathrm{t}_{2}-\mathrm{t}_{1}\right) \\
& \text { RGR-R }=\left(\log \mathrm{R}_{2}-\log \mathrm{R}_{1}\right) /\left(\mathrm{t}_{2}-\mathrm{t}_{1}\right) \\
& \text { RGR-Total }=\text { RGR-L }+ \text { RGR-S }+ \text { TCR-R }
\end{aligned}
$$

In which the variables are represented by $\mathrm{L}_{1}=$ initial leaf $(\mathrm{g}), \mathrm{L}_{2}=$ final leaf $(\mathrm{g}), \mathrm{S}_{1}=$ initial stem $(\mathrm{g}), \mathrm{S}_{2}=$ final stem $(\mathrm{g})$, $\mathrm{R}_{1}=$ initial root $(\mathrm{g}), \mathrm{R}_{2}=$ final root $(\mathrm{g}), \mathrm{t}_{1}=$ initial time (months) and $\mathrm{t}_{2}=$ final time (months).

\section{NUTRIENTS ANALYSIS}

The determination of macro and micronutrients concentration was determined by the plant material, divided in leaf, stem and root and grinded until a thin powder was obtained. The concentration of total nitrogen was determined using the titration method (Vitti \& Ferreira, 1997). $1 \mathrm{~g}$ of dry plant material was digested in a $5 \mathrm{ml}$ tube containing sulfuric acid, salts and catalysts. This mixture was heated until $350^{\circ} \mathrm{C}$ and the resulting solution distilled and titrated. Phosphorus was extracted using 0.5 g plant material (dry weight) in nitro-perchloric solution. The resulting solution was heated until $210^{\circ} \mathrm{C}$ and the phosphorus concentration determined using a spectrophotometer at 725nm (Vitti \& Ferreira, 1997). In the same nitro-perchloric extract the concentration of the nutrients $\mathrm{Ca}, \mathrm{Mg}, \mathrm{K}, \mathrm{Fe}, \mathrm{Zn}$, and $\mathrm{Mn}$ was determined by spectrophotometry of atomic absorption 
(Perkin Elmer 1100B, Uberlingen, Germany) as described by Miyazawa et al.(1999).

\section{PIGMENT ANALYSIS}

The contents of chloroplastid pigments were determined in fully expanded leaves, from which $0.1 \mathrm{~g}$ of fresh vegetal material was macerated in $10 \mathrm{~mL}$ of acetone $80 \%$ containing magnesium carbonate $\left(\mathrm{MgCO}_{3}\right) .10 \mathrm{~mL}$ of acetone $100 \%$ was then immediately added. The macerated solution was filtered using qualitative filter paper and the absorbance determined using spectrophotometry (JENWAY 6105 UV/VIS. Spectrophotometer), at wavelengths of $663 \mathrm{~nm}$ (chlorophyll a), $645 \mathrm{~nm}$ (chlorophyll $b$ ) and $480 \mathrm{~nm}$ (carotenoids). The chlorophyll and carotenoids contents were calculated according to Hendry \& Prince (1993).

\section{CHLOROPHYLL A FLUORESCENCE MEASUREMENTS}

Chlorophyll $a$ fluorescence was determined with a portable fluorometer (Plant Efficiency Analyzer-PEA, MK2-9600Hansatech, Norfolk, UK), between 9:00 and 11:00 a.m., in leaves situated in the third middle of the plants. From each treatment 5 leaves were chosen (subsamples) to compose the repetitions. A. rosaeodora seedlings were acclimated to darkness for a period of 20 minutes, which, according to pre-tests, was sufficient for complete oxidation of the electron transport photosynthetic system, during exposure to pulse of light saturated at high irradiance $\left(2250 \mu \mathrm{mol} \mathrm{m}^{-2} \mathrm{~s}^{-1}\right.$ and a wavelength of $650 \mathrm{~nm}$ for $5 \mathrm{~s}$ at 12 bit resolution). Variables of chlorophyll $a$ fluorescence were determined according to Gonçalves \& Santos Junior (2005). From fast and slow kinetics of fluorescence induction, the initial fluorescence $\left(\mathrm{F}_{\mathrm{o}}\right)$, the maximum fluorescence $\left(\mathrm{F}_{\mathrm{m}}\right)$, the variable fluorescence $\left(\mathrm{F}_{\mathrm{v}}=\right.$ $\mathrm{F}_{\mathrm{m}}-\mathrm{F}_{\mathrm{o}}$ ) and the maximum photochemical efficiency of PSII $\left(\mathrm{F}_{\mathrm{v}} / \mathrm{F}_{\mathrm{m}}\right)$ were obtained. The measurements were performed at the beginning of the experiment (time zero), at 60 days, and 120 days of experiment.

\section{NITRATE REDUCTASE ACTIVITY ANALYSIS}

The nitrate reductase (RN, E.C.1.6.6.1) activity was determined in plant leaves using "in vivo" analysis according to Hageman \& Reed (1980) with small modifications. For this $0.5 \mathrm{~g}$ of leaf tissue was weighed, then transferred to Erlenmeyer $(50 \mathrm{ml})$ containing half the incubation solution $(0.1 \mathrm{M}$ potassium phosphate $(\mathrm{pH} 7.5), 1 \%(\mathrm{v} / \mathrm{v}) \mathrm{n}$-propyl alcohol, and $0.1 \mathrm{M} \mathrm{KNO}_{3}$ ). This solution, containing the leaf disks, was submitted to a vacuum for 5 minutes, and the receptacles were immediately placed in a double boiler and shaked. After intervals of 30 and 60 minutes of incubation, aliquots of 1 $\mathrm{ml}$ were collected and combined with $1 \mathrm{ml}$ of sulfanilamide containing $1 \% \mathrm{HCl} 1.5 \mathrm{~N}, 1 \mathrm{ml}$ of N-2-naftil ethylene. The absorbance readings were completed at a length of $540 \mathrm{~nm}$. The concentration of nitrite was determined in half of the incubation time from the standard curve.

\section{EXPERIMENTAL DESIGN AND STATISTICAL ANALYSIS}

The experimental design was completely randomized with five treatments and four repetitions. The results were submitted to variance analysis and the means were compared by the Tukey test at $5 \%$ probability. The regression analyses were adjusted using the following criteria: 1 ) the significance of the equation coefficients 2) adequacy of the determining coefficient $\left(\mathrm{R}^{2}\right)$. The statistical analyses were conducted using the software SAEG/UFV (version 5.0).

\section{RESULTS AND DISCUSSION}

In the present work, different $\mathrm{NO}_{3}^{-}: \mathrm{NH}_{4}^{+}$ratios were tested in $A$. rosaeodora seedlings aiming the establishment of more appropriate conditions for cultivation of this species. The $\mathrm{pH}$ measurement revealed that there was a linear increase in the $\mathrm{pH}$ value in the percolated solution with increasing of $\mathrm{NO}_{3}^{-}$concentration in relation to $\mathrm{NH}_{4}^{+}$in the culture substrate. The lowest $\mathrm{pH}$ (5.1) was observed in the substrate solution supplied only with ammonium $\left(0: 100 \% \mathrm{NO}_{3}^{-}: \mathrm{NH}_{4}^{+}\right)$ and the highest $\mathrm{pH}$ (6.4) in the solution supplied only with nitrate (100:0\% $\left.\mathrm{NO}_{3}^{-}: \mathrm{NH}_{4}^{+}\right)$(Figure 1). An equilibrium was observed in the $\mathrm{pH} 5.6$ when it was used equal ratios of $\mathrm{NO}_{3}{ }^{-}$and $\mathrm{NH}_{4}^{+}(50: 50 \%)$ (Figure 1). These results confirm the effect of rhizosphere acidification and basification as result of different levels of $\mathrm{NH}_{4}{ }^{+}$and $\mathrm{NO}_{3}{ }^{-}$, respectively. According to Lasa et al. (2001) the uptake of $\mathrm{NH}_{4}^{+}$ions results in the efflux of hydrogen ions in the root decreasing the rhizosphere pH. Öhlund \& Näsholm (2001) observed a decrease in culture solution $\mathrm{pH}$ in conifer seedlings when high levels of $\mathrm{NH}_{4}^{+}$were present. Similar results were observed in the orchid Catasetum fimbriatum (Majerowicz et al. 2000). The results observed with the $\mathrm{pH}$ measurement suggested that the addition of $\mathrm{NO}_{3}{ }^{-}$can be an important factor for the growth of A. rosaeodora seedlings. In function of the $\mathrm{pH}$ value obtained in seedlings treated with $100 \% \mathrm{NO}_{3}^{-}: \mathrm{NH}_{4}^{+}(\mathrm{pH}$ 6.4), it might be possible that the uptake of others nutrients was favored in relation to treatments with high levels of $\mathrm{NH}_{4}^{+}$. In soils containing low levels of hydrogen the availability of essential nutrients is normally higher.

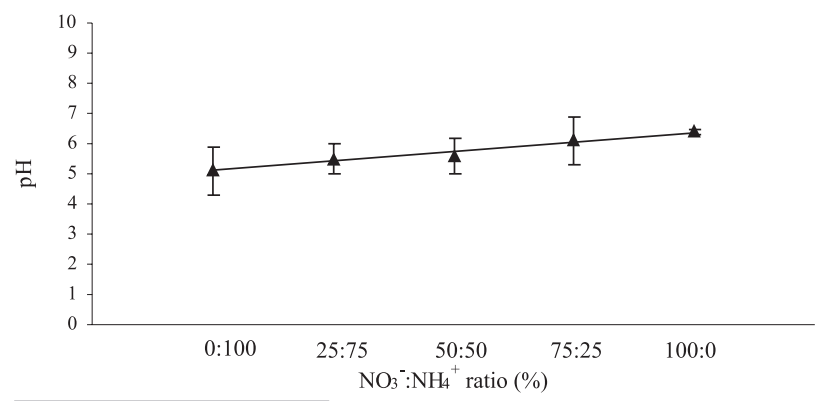

Figure 1 - The monitoring of the $\mathrm{pH}$ in the nutritive solutions with different $\mathrm{NO}_{3}: \mathrm{NH}_{4}{ }^{+}$ratio in the growth of Aniba rosaeodora seedlings. 
The growth of $A$. rosaeodora seedlings was significantly affected by the different ratios of $\mathrm{NO}_{3}^{-}: \mathrm{NH}_{4}^{+}$(Figure $2 \mathrm{~A}-\mathrm{D}$ ). The highest rates of biomass accumulation were observed in plants submitted to treatments with high levels of $\mathrm{NO}_{3}^{-}$in detriment to high concentration of $\mathrm{NH}_{4}^{+}$. In addition, it was observed that plants submitted to $0: 100 \mathrm{NO}_{3}^{-}: \mathrm{NH}_{4}^{+}$ exhibited the lowest values for accumulation of stem, root and total biomass when compared with the other treatments (Figure 2A-D).

It has been demonstrated that high levels of plant growth, in different species, are obtained when $\mathrm{NO}_{3}{ }^{-}$is in a higher proportion in relation to $\mathrm{NH}_{4}^{+}$in the culture solution (Pereira et al., 1996; Frechilla et al., 2001; Lasa et al., 2001, Öhlund \& Näsholm, 2001). In many cases, the inhibition of plant growth is related to a decrease in the rhizosphere $\mathrm{pH}$ caused by the uptake of $\mathrm{NH}_{4}^{+}$(Lasa et al., 2001). This may be occurred in the substrates of $A$. rosaeodora seedlings treated with $\mathrm{NH}_{4}^{+}$, in which lower $\mathrm{pH}$ values were recorded. This fact can induce the acidification of the growth substrate, potentially compromising root activity. However, in situations of low $\mathrm{pH}$ the assimilation of $\mathrm{NH}_{4}^{+}$can be favored. Since this form of the $\mathrm{N}$-mineral is used directly in the synthesis of amines and amino acids plants can conserve more energy (Sandoval et al., 1995). Bedell et al. (1999) studying the incorporation of biomass in Pseudotsuga menziessi observed higher rates of growth when those plants were treated with $\mathrm{NH}_{4}^{+}$. Similar results were obtained in Betula alleghaniensis and Pinus strobus seedlings (Bauer \& Berntson, 2001). Furthermore, there is also evidence that an equal ratio of $\mathrm{NO}_{3}: \mathrm{NH}_{4}^{+}$can promote a better plant development. In Bactris gasipaes seedlings the maximum production of biomass (dry weight) was observed when equal ratios of $\mathrm{NO}_{3}^{-}: \mathrm{NH}_{4}^{+}$were used (Pacheco et al., 1998). For $A$. rosaeodora, independently of the plant segment analyzed high levels of plant growth were observed when $\mathrm{NO}_{3}^{-}$ was used in higher concentrations in relation to $\mathrm{NH}_{4}^{+}$.

The concentration of nitrogen $(\mathrm{N})$ in the leaf was higher in seedlings supplemented with a ratio of $75: 25 \% \mathrm{NO}_{3}-$ $: \mathrm{NH}_{4}{ }^{+}$when compared with seedlings supplemented with 25:75 and $0: 100 \%$ of $\mathrm{NO}_{3}^{-}: \mathrm{NH}_{4}^{+}$. On the other hand, no difference was observed between the concentrations of $\mathrm{N}$ in the stem and in the root (Figure 3A). The phosphorus (P) contents in the leaves and in the root were higher when $\mathrm{NO}_{3}$ - predominated in cultivation solution in a ratio of $75: 25 \% \mathrm{NO}_{3}^{-}: \mathrm{NH}_{4}^{+}$(Figure 3B). For potassium, (K) it was verified that plants submitted to the treatments of $75: 25$ and 100:0\% $\mathrm{NO}_{3}^{-}: \mathrm{NH}_{4}^{+}$exhibited higher concentrations of $\mathrm{K}$ in the roots when compared with the other treatments (Figure $3 \mathrm{C})$. For calcium $(\mathrm{Ca})$ and magnesium $(\mathrm{Mg})$, it was not observed significant differences in their levels in leaves. However, concerning the concentration of these cations in the stem, it was observed that plants supplemented with 0:100 $\% \mathrm{NO}_{3}: \mathrm{NH}_{4}{ }^{+}$exhibited the highest levels of $\mathrm{Ca}$ and $\mathrm{Mg}$ for stem biomass when compared with plants supplemented with 25:75 and 50:50\% $\mathrm{NO}_{3}^{-}: \mathrm{NH}_{4}^{+}$(Figure 3D and 3E). In addition, it was verified that plants supplemented with 100:0 \% $\mathrm{NO}_{3}: \mathrm{NH}_{4}{ }^{+}$exhibited the highest values of $\mathrm{Ca}$ in the roots, whereas in plants supplemented with $75: 25 \% \mathrm{NO}_{3}$. $: \mathrm{NH}_{4}{ }^{+}$it was recorded the highest levels of $\mathrm{Mg}$ (Figure 3D and 3E). In Bactris gasipaes seedlings, it was observed that a higher proportion of $\mathrm{NH}_{4}^{+}$favored the absorption of $\mathrm{N}$ and $\mathrm{P}$ by the plant and increase the levels of $\mathrm{Ca}, \mathrm{K}$ and, $\mathrm{Mg}$ in the shoots. However, when roots were analyzed the uptake of these nutrients was less evident (Pacheco et al., 1998). In the tree species Senna multijuga and Jacaranda mimosifolia it was verified that fertilization with $\mathrm{NO}_{3}$ - favors a greater accumulation of $\mathrm{Ca}$ and $\mathrm{K}$ in comparison with those fertilized with $\mathrm{NH}_{4}^{+}$(Pereira et al., 1996). In conifer seedlings submitted to high concentrations of $\mathrm{NH}_{4}^{+}$, an imbalance was observed in the accumulation of nutrients. (Öhlund \& Näsholm, 2001). For micronutrients, it was observed that the concentration of iron $(\mathrm{Fe})$ in leaves, stem, and roots was the same in seedlings submitted to different treatments (Figure 3F). Concerning the concentration of zinc $(\mathrm{Zn})$ in leaves it was observed that the seedlings submitted to the treatment 100:0 \% $\mathrm{NO}_{3}$ $: \mathrm{NH}_{4}{ }^{+}$exhibited the highest concentration when compared with plants in the treatments $25: 75$ and $0: 100 \% \mathrm{NO}_{3}^{-}: \mathrm{NH}_{4}^{+}$ (Figure 3G). For manganese (Mn), there was no difference between the concentrations present in the leaf and in the stem for all treatments tested. Nevertheless, in the root the highest concentration was found in the treatment with $75: 25 \%$ of $\mathrm{NO}_{3}^{-}: \mathrm{NH}_{4}^{+}($Figure $3 \mathrm{H})$.

Table 1 - Concentration of chloroplastid pigments $\left(\mu \mathrm{mol} \mathrm{m} \mathrm{m}^{-2}\right)$ and chlorophyll a / $b$ ratio $(\mathrm{Chl} \mathrm{a} \mathrm{/} b)$ and chlorophyll/carotenoids ratio $\left(\mathrm{Chl}_{\text {tot }} / \mathrm{C}_{\mathrm{x}+\mathrm{c}}\right)$ in Aniba rosaeodora seedlings submitted to different $\mathrm{NO}_{3}: \mathrm{NH}_{4}{ }^{+}$ratio.

\begin{tabular}{lllllll}
\hline $\begin{array}{l}\mathrm{NO}_{3}-\mathrm{NH}_{4}{ }^{+} \text {ratio } \\
(\%)\end{array}$ & $\begin{array}{l}\text { Chlrophyll a } \\
\mu \text { mol m}{ }^{-2}\end{array}$ & Chlorophyll $b$ & Total Chlorophyll total & Carotenoids & Chl $\mathrm{a} / \mathrm{b}$ & $\mathrm{Chl}_{\text {tot }} / \mathrm{C}_{\mathrm{x}+\mathrm{c}}$ \\
\hline $0: 100$ & $189 \pm 29 \mathrm{~b}$ & $97 \pm 17 \mathrm{a}$ & $286 \pm 46 \mathrm{~b}$ & $131 \pm 19 \mathrm{a}$ & $1,95 \pm 0,09 \mathrm{~b}$ & $2,17 \pm 0,04 \mathrm{~b}$ \\
$25: 75$ & $263 \pm 48 \mathrm{ab}$ & $110 \pm 10 \mathrm{a}$ & $373 \pm 57 \mathrm{ab}$ & $157 \pm 14 \mathrm{a}$ & $2,38 \pm 0,23 \mathrm{ab}$ & $2,36 \pm 0,15 \mathrm{~b}$ \\
$50: 50$ & $261 \pm 49 \mathrm{ab}$ & $110 \pm 23 \mathrm{a}$ & $371 \pm 71 \mathrm{ab}$ & $150 \pm 27 \mathrm{a}$ & $2,37 \pm 0,19 \mathrm{ab}$ & $2,46 \pm 0,03 \mathrm{ab}$ \\
$75: 25$ & $332 \pm 30 \mathrm{a}$ & $128 \pm 11 \mathrm{a}$ & $461 \pm 41 \mathrm{a}$ & $168 \pm 13 \mathrm{a}$ & $2,58 \pm 0,03 \mathrm{a}$ & $2,75 \pm 0,13 \mathrm{a}$ \\
$100: 0$ & $239 \pm 23 \mathrm{ab}$ & $101 \pm 14 \mathrm{a}$ & $340 \pm 31 \mathrm{ab}$ & $154 \pm 19 \mathrm{a}$ & $2,37 \pm 0,34 \mathrm{ab}$ & $2,21 \pm 0,16 \mathrm{~b}$ \\
\hline
\end{tabular}

Mean values \pm S.D. followed by same letters for treatments are not different at $P \leq 0.05$ using Tukey test. 

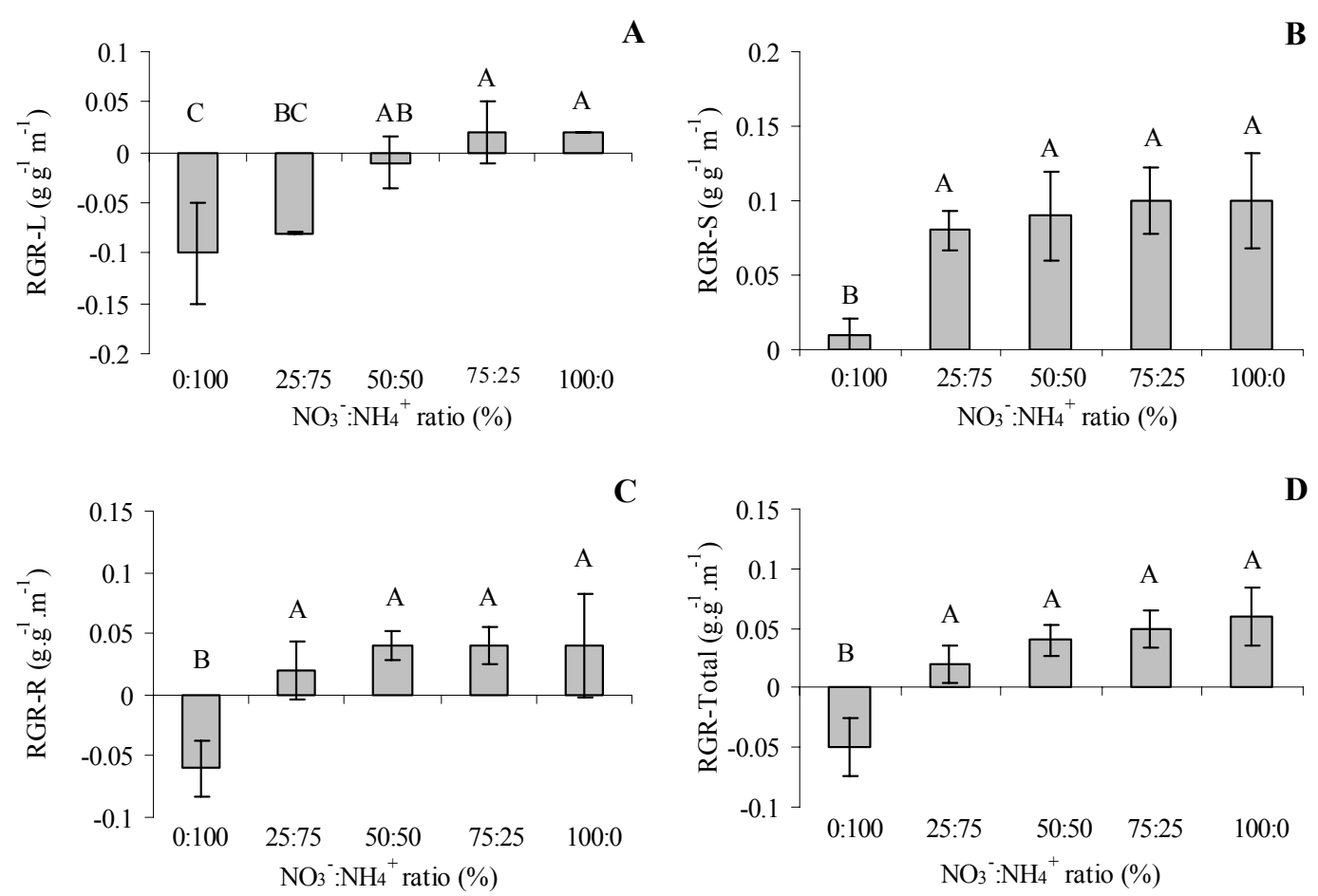

Figure 2 - Relative growth rate of Aniba rosaeodora seedlings submitted to different ratios of $\mathrm{NO}_{3}-\mathrm{NH}_{4}^{+}\left(\mathrm{T}_{1}=0: 100 \%, \mathrm{~T}_{2}=25: 75 \%, \mathrm{~T}_{3}=50: 50 \%, \mathrm{~T}_{4}=\right.$ $75: 25 \%$ and $T_{5}=100: 0 \%$ ), where RGR-L = relative growth rate of leaf mass, RGR-C = relative growth rate of stem mass, $R G R-R=$ relative growth rate of root mass and RGR-Total = relative growth rate of total mass. Mean values \pm S.D. followed by same letters for treatments are not different at $P \leq 0.05$ using Tukey test.

For pigment contents, it was observed that the highest value of chlorophyll $a(\mathrm{Chl} a)$ and total chlorophyll $\left(\mathrm{Chl}_{\text {tor }}\right)$ were found in plants supplemented with 75:25\% $\mathrm{NO}_{3}^{-}: \mathrm{NH}_{4}^{+}$, these being $76 \%$ and $61 \%$ greater than the average values observed in plants submitted to the treatment of $0: 100 \% \mathrm{NO}_{3}^{-}$ $: \mathrm{NH}_{4}^{+}$, respectively (Table 1 ). In addition, it was verified that there was no difference in the concentrations of chlorophyll $b(\mathrm{Chl} b)$ and carotenoids $\left(\mathrm{C}_{\mathrm{x}+c}\right)$ among treatments. For chlorophyll $a / b$ ratio $(\mathrm{Chl} a / b)$ it was verified that plants in the treatment $75: 25 \% \mathrm{NO}_{3}: \mathrm{NH}_{4}{ }^{+}$exhibited a value $32 \%$ higher than the plants in the treatment $0: 100 \% \mathrm{NO}_{3}: \mathrm{NH}_{4}^{+}$. As for the chlorophyll/carotenoids ratio $\left(\mathrm{Chl} / \mathrm{C}_{\mathrm{xtc}}\right)$ plants supplemented with $75: 25 \% \mathrm{NO}_{3}: \mathrm{NH}_{4}^{+}$exhibited values close to 27,24 and $17 \%$ higher than plants in the treatments 0:100, 100:0 and 25:75\% $\mathrm{NO}_{3}: \mathrm{NH}_{4}^{+}$, respectively (Table 1). In general, a gradual increase for chloroplastid pigments (chlorophyll and carotenoids) was recorded with increasing levels of $\mathrm{NO}_{3}^{-}$in the nutritive solution. Majerowicz et al. (2000) observed that Catasetum fimbriatum plants treated with $\mathrm{NO}_{3}^{-}$exhibited low chlorophyll contents, in relation to the use of $\mathrm{NH}_{4}^{+}$. It might be possible that $A$. rosaeodora has a different demand showing a preference for a solution with a higher concentration of $\mathrm{NO}_{3}^{-}$instead of $\mathrm{NH}_{4}^{+}$.
Chlorophyll $a$ fluorescence has been used to evaluate the capacity for acclimatization of species under stress; this fact can be shown through the photochemical efficiency of PSII (Krause \& Weis, 1991). Decreases in the photochemical efficiency of PSII are normally associated with low chlorophyll contents. The results obtained in our experiments suggested that, high levels of $\mathrm{NO}_{3}{ }_{3}^{-}$can induce in $A$. rosaeodora seedlings a higher capacity of acclimatation.

The photochemical efficiency of PSII is analyzed according to the variables of chlorophyll $a$ fluorescence $\left(\mathrm{F}_{\mathrm{o}}, \mathrm{F}_{\mathrm{v}}, \mathrm{F}_{\mathrm{m}} \mathrm{e}\right.$ $\left.\mathrm{F}_{\mathrm{v}} / \mathrm{F}_{\mathrm{m}}\right)$. A. rosaeodora plants submitted to the analysis of chlorophyll $a$ fluorescence variables, at 0,60 and 120 days, after the application of the treatments, exhibited values with an indicative of fluorescence stress, especially after 60 days of exposure to the conditions tested (Figure 4A). In addition, it was verified that the $\mathrm{F}_{0}$ variable exhibited the highest value at 60 days after the application of the treatments, and the smallest values at 120 days (Figure 4A). Considering only the variable $\mathrm{F}_{\mathrm{o}}$ the highest value was observed in the treatment with $25: 75 \% \mathrm{NO}_{3}^{-}: \mathrm{NH}_{4}^{+}$, and the lowest value in the treatment with $75: 25 \% \mathrm{NO}_{3}^{-}: \mathrm{NH}_{4}{ }^{+}$. For the variable $\mathrm{F}_{\mathrm{v}}$, the lowest value was observed in the treatment with $0: 100 \% \mathrm{NO}_{3}^{-}: \mathrm{NH}_{4}^{+}$, at 60 and 120 days (Figure $4 \mathrm{~B})$. For the variable $\mathrm{F}_{\mathrm{m}}$, there was 

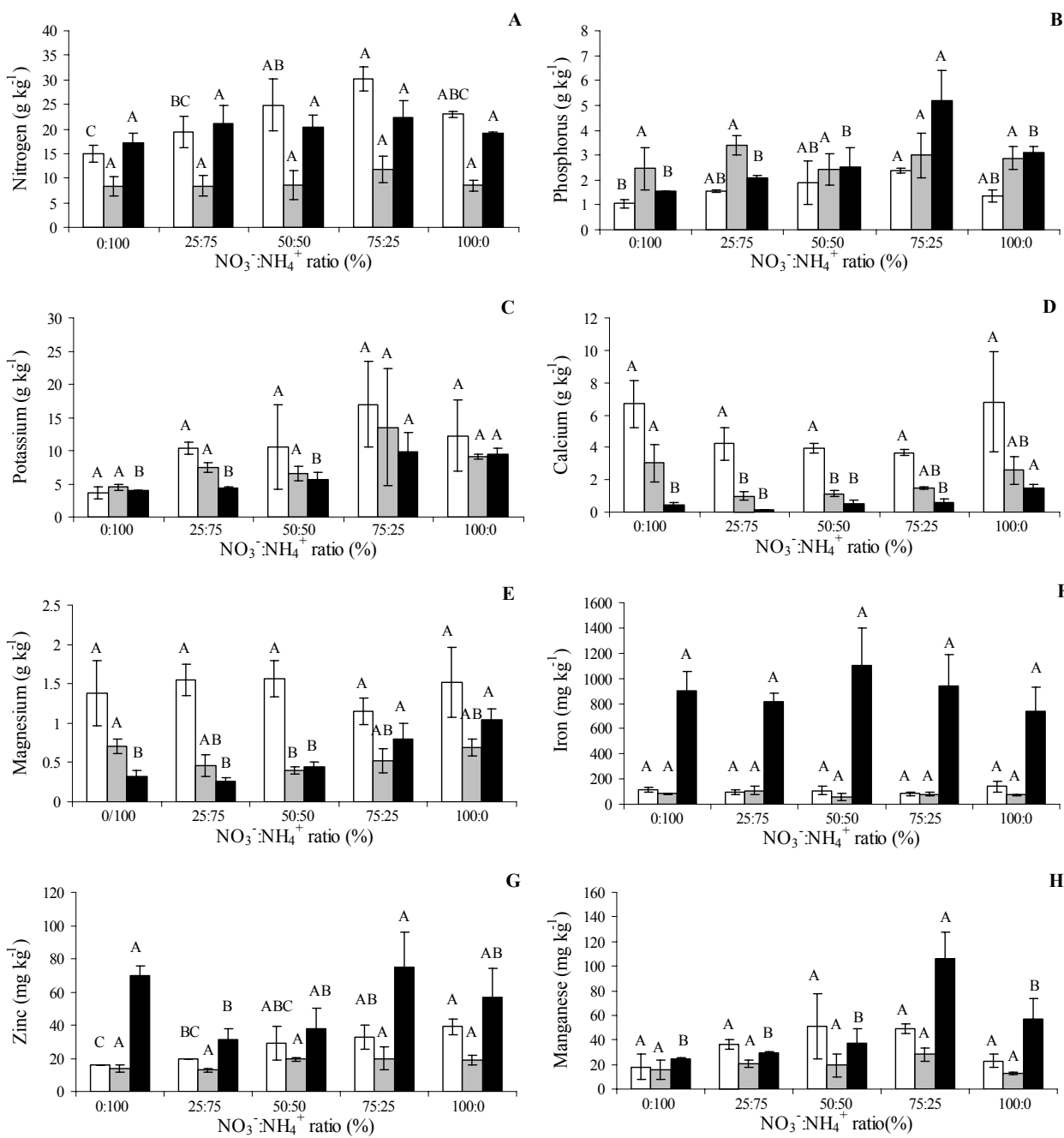

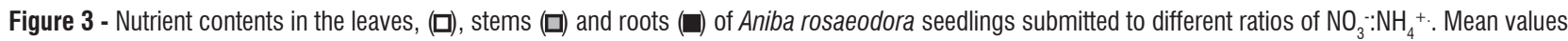
\pm S.D. followed by s ame letters for treatments are not different at $P \leq 0.05$ using Tukey test.

no difference between the periods of 0,60 and 120 days of treatment (Figure 4C).

Taken into account the variable $\mathrm{F}_{\mathrm{v}} / \mathrm{F}_{\mathrm{m}}$, it was observed a loss of photochemical efficiency of PSII at 60 days of experiment. However in the treatment 75:25\% $\mathrm{NO}_{3}^{-}: \mathrm{NH}_{4}^{+}$no difference was observed in the three periods analyzed (Figure $4 \mathrm{D})$. At 120 days, the average $\mathrm{F}_{\mathrm{v}} / \mathrm{F}_{\mathrm{m}}$ values were higher in the treatment with $75: 25 \% \mathrm{NO}_{3}^{-}: \mathrm{NH}_{4}^{+}$when compared with plants supplemented with 0:100 and 25:75\% $\mathrm{NO}_{3}^{-}: \mathrm{NH}_{4}^{+}$. This result could indicate a high degree of adaptation in $A$. rosaeodora to the nutritive solution containing high levels of nitrate in relation to ammonium, which can also represent a greater photochemical efficiency of PSII. The lowest values of $\mathrm{F}_{\mathrm{v}} / \mathrm{F}_{\mathrm{m}}$ in plants submitted to the treatment with $0: 100 \%$ $\mathrm{NO}_{3}^{-}: \mathrm{NH}_{4}^{+}$can be related to the harmful effect of $\mathrm{NH}_{4}^{+}$ which, when accumulated, may promote the destruction of cell membranes.
The nitrate reductase activity $(\mathrm{RN})$ was determined in leaves of $A$. rosaeodora. According to our results, the highest nitrate reductase activity was recorded in seedlings supplemented with 100:0\% $\mathrm{NO}_{3}^{-}: \mathrm{NH}_{4}^{+}$(Figure 5). This result suggests that $A$. rosaeodora shows a positive response to the reduction of $\mathrm{NO}_{3}{ }^{-}$to $\mathrm{NH}_{3}$. Similar results were observed in Catasetum fimbriatum and Ananas comosus plants when the $\mathrm{NO}_{3}{ }^{-}$concentration in the substrate was increased (Majerowicz et al., 2000; Nievola \& Mercier, 2001).

A. rosaeodora seedlings cultivated in the solution containing only $\mathrm{NO}_{3}^{-}$exhibited the highest accumulation for root and total biomass. The $\mathrm{pH}$ change provoked by the form of $\mathrm{N}$ in the solution was important for the uptake of nutrients. The preference for $\mathrm{N}$ in the form $\mathrm{NO}_{3}^{-}$was corroborated by the positive activity of $\mathrm{RN}$, suggesting a more efficient action of $\mathrm{NO}_{3}{ }^{-}$when compared to $\mathrm{NH}_{4}^{+}$for growth and functionality of this species. In addition, as $A$. rosaedora is a 

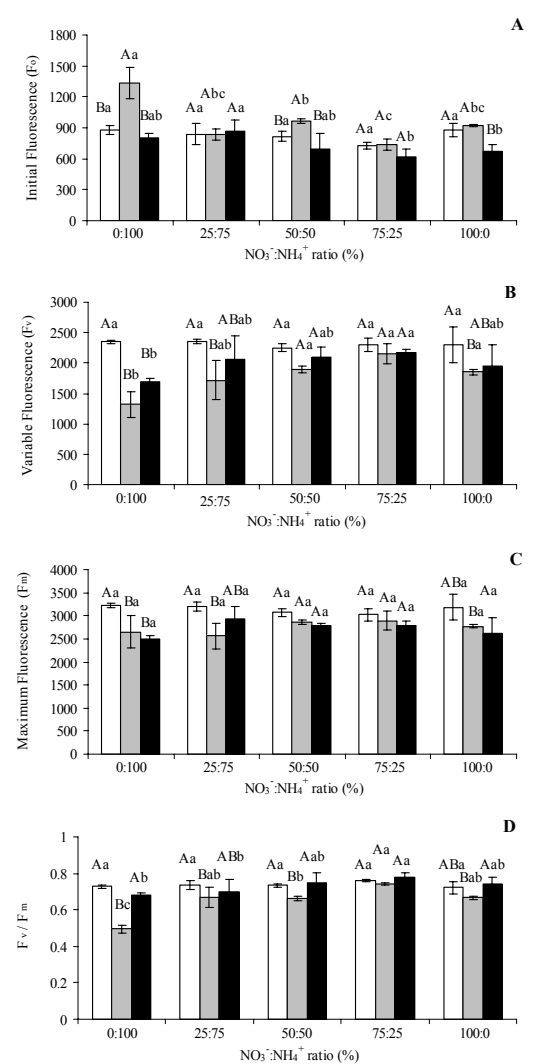

Figure 4 - Photochemical efficiency of photosystem II in Aniba rosaeodora seedlings submitted to different ratios of $\mathrm{NO}_{3}: \mathrm{NH}_{4}{ }^{+}\left(\mathrm{T}_{1}=0: 100 \%, \mathrm{~T}_{2}=\right.$ $25: 75 \%, T_{3}=50: 50 \%, T_{4}=75: 25 \%$ and $T_{5}=100: 0 \%$ ), where $F_{0}=$ initial fluorescence, $F_{v}=$ variable fluorescence, $F_{m}=$ maximum fluorescence, and the ratio $F_{\sqrt{ }} F_{m}$, in three different periods: 0 (口), 60 (ㅁ) e 120 (口) days, respectively. Mean values \pm S.D. followed by same capital letters for days and small letter treatments are not different at $P \leq 0.05$ using Tukey test.

slow-growing species the uptake of $\mathrm{NO}_{3}{ }_{3}^{-}$could be preferred in function of the harmful effects of $\mathrm{NH}_{4}^{+}$accumulation to the cell membranes. It might be possible that $A$. rosaeodora seedlings, despite inhabiting environments with potentially reduced redox, exhibit a preference for the utilization of $\mathrm{N}$ in the form $\mathrm{NO}_{3}^{-}$when compared with $\mathrm{NH}_{4}^{+}$.

\section{ACKNOWLEDGEMENTS}

We acknowledge Brazil's Ministry of Science and Technology (MCT), the Agency of Japanese Cooperation, the (Project JICA, FASE II N. 309-1064-E-1), Finep-CTPetro and $\mathrm{CNPq}$ for their financial support in the execution of part of the present study (project AI 553316/2005-2). JFC Gonçalves acknowledges fellowship granted by the National Council for Scientific and Technological Development (CNPq, Brazil).

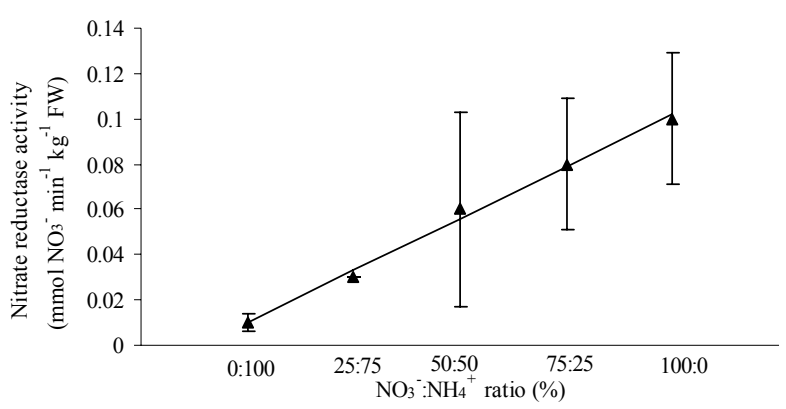

Figure 5 - Nitrate reductase activity (NR) in leaves of Aniba rosaeodora seedlings submitted to different ratios of $\mathrm{NO}_{3}^{-:}: \mathrm{NH}_{4}^{+}$.

\section{LITERATURE CITED}

Bauer, G.A.; Berntson G.M. 2001. Ammonium and nitrate acquisition by plants in response to elevated $\mathrm{CO}_{2}$ concentration: the roles of root physiology and architecture. Tree Physiol., 21: 137-144.

Bedell, J.P.; Chalot, M.; Garnier, A.; Botton B. 1999. Effects of nitrogen source on growth and activity of nitrogen-assimilating enzymes in Douglas-fir seedlings. Tree Physiol., 19: 205-210.

Bohn, W. 1979. Methods of studying root systems. Springer-Verlag, Berlin.

Bugbee, B.G. (1996). Growth, analysis and yield components. In: Salisbury FB (ed), Units, Symbols, and Terminology for plant physiology. Oxford University Press. p. 115-119.

Clark, R.B. 1982. Nutrient solution growth of sorghum and corn in mineral nutrition studies. J. Plant Nutr., 5: 1039-1057.

Canton, F.R.; Suarez. M.F.; Canovas, F.M. 2005. Molecular aspects of nitrogen mobilization and recycling in trees. Photosynth. Res., 83: $265-278$.

Clay, J.W.; Sampaio, P.T.B.; Clement, C.R. 2000. Biodiversidade amazônica: exemplos e estratégias de utilização. Programa de Desenvolvimento Empresarial e Tecnológico, Manaus.

Davanso, V.M.; Souza, L.A.; Medri, M.E.; Pimenta, J.A.; Bianchini, E. (2002). Photosynthesis, growth and development of Tabebuia avellanedae Lor. Ex Griseb. (Bignoniaceae) in flooded soil. Braz. Archiv. Biol Tech., 45(3): 375-384.

David, E.R; Bert M.C. 2005. Effects of nitrogen form on nutrient uptake and physiology of Fraser fir (Abies fraseri). Forest Ecology and Management., 219: 69-80.

Evans, G.C. 1972. The quantitative analysis of plant growth. University of California Press, Berkeley.

Frechilla, S.; Lasa, B.; Ibarretxe, L.; Lamsfus, C.; Aparicio-Tejo, P. 2001. Pea responses to saline stress is affected by the source of nitrogen nutrition (ammonium or nitrate). Plant Growth Regul., 35(2):171-179.

Gonçalves, J.F.C.; Marenco, R.A.; Vieira, G. 2001. Concentration of photosynthetic pigments and chlorophyll fluorescence of mahogany and tonka bean under two light environments. Braz. J. Plant Physiol., 13(2): 149-157. 
Gonçalves, J.F.C.; Barreto, D.C.S.; Santos Junior, U.M.; Fernandes, A.V.; Sampaio; P.T.B.; Buckeridge, M.S. 2005. Growth, photosynthesis and stress indicators in young rosewood plants (Aniba rosaeodora Ducke) under different light intensities. Braz. J. Plant Physiol., 17(3): 325-334.

Gonçalves, J.F.C.; Santos Junior, U. M. 2005. Utilization of the chlorophyll a fluorescence technique as a tool for selecting tolerant species to environments of high irradiance. Braz. J. Plant Physiol., 17(3): 307-313.

Hageman, R.H.; Reed, A.J. 1980. Nitrate reductase from higher plants. Methods Enzymol., 69: 270-280.

Hendry, G.A.F.; Price, A.H. 1993. Stress indicators: chlorophylls and carotenoids. In: Hendry, G.A.F; Grime, J.P. (eds), Methods in Comparative Plant Ecology, pp.148-152. Champman \& Hall, London, UK.

Hoagland, P.L.; Arnon, D.I. 1950. The water culture methods for growing plants without soil. Berkeley. California Agricultural Experiment Station. Circular no 347, 39pp.

Hunt, R. 1982. Plant growth curves: the functional approach to plant growth analysis. Edward Arnold, London.

Kaiser, W.M.; Huber, S.C. 2001. Post-translational regulation of nitrate reductase: mechanism, physiological relevance and environmental triggers. J. Exp. Bot., 52: 1980-1989.

Krause, G.H.; Weis, E. 1991. Chlorophyll fluorescence and photosynthesis: the basis. Annu. Rev. Plant Physiol. Mol. Biol., 42: 313-349.

Lasa, B.; Frechilla, S.; Lamsfus, P.M.; Tejo, A. 2001. The sensitivity to ammonium nutrition is related to nitrogen accumulation. Sci. Hortic., 91: 143-152.

Lawlor, D.W. (2002) Carbon and nitrogen assimilation in relation to yield: mechanisms are the key to understanding production systems. J. Exp. Bot., 53: 773-787.

Lemos, G.B.; Delú, Filho. N.; Oliveira, L.E.M.; Purcino, A.A.C. 1999. Atividades das enzimas e assimilação do nitrogênio em plantas jovens de seringueira cultivadas com diferentes relaçôes de nitrato e amônio. Rev. Bras. Fisiol. Veg., 11(2): 113-118.

Majerowicz, N.; Kerbauy, G.B.; Nievola, C.C.; Suzuki, R.M. 2000. Growth and nitrogen metabolism of Catasetum fimbriatum (orchidaceae) grown with different nitrogen sources. Environ. Exp. Bot., 44: 195-206.

Majerowicz, N.; Kerbauy, B. 2002. Effects of nitrogen forms on dry matter partitioning and nitrogen metabolism in two contrasting genotypes of Catasetum fimbriatum (Orchidaceae). Environ. Exp. Bot., 47: 249-258.

Marenco, R.A.; Gonçalves, J.F.C.; Vieira, G. 2001. Photosynthesis and leaf nutrient contents in Ochroma pyramidale (Bombacaceae). Photosynthetica, 39(4): 539-543.

May PH, Barata L.E.S. 2004. Rosewood exploitation in the Brazilian Amazon: options for sustainable production. Econ. Bot., 58(2): 257-265.
Meyer, S; Cerovic, Z.G.; Goulas, Y.; Montpied, P.; Demotes-Mainard, S.; Bidel, L.P.R.; Moya, I.; Dreyer, E. 2006. Relationships between optically assessed polyphenols and chlorophyll contents and leaf mass per area ratio in woody plants: a signature of the carbon-nitrogen balance within leaves? Plant, Cell and Environment, 1365-3040, 1-11.

Miyazawa, M.; Pavan, M.A.; Muraoka, T.; Carmo, C.A.F.S.; Melo, W.J. 1999. Análises químicas de tecido vegetal. In: Manual de análises químicas do solos, plantas e fertilizantes. Empresa Brasileira de Pesquisa Agropecuária. Brasília, DF. p. 172-223.

Nievola, C.C.; Mercier, H. 2001. Variações diurnas da atividade in vivo da redutase do nitrato em abacaxizeiro (Ananas comosus (L.) Merr. - Bromeliaceae). Rev. Bras. Bot., 24(3): 295-301.

Öhlund, J.; Nasholm, T. 2001. Growth of conifer seedlings on organic and inorganic nitrogen sources. Tree Physiol., 21(18): 1319-1326.

Pacheco, R.G.; Cardoso, A.A.; Martinez, H.P.; Cruz, C.D.; Barros, N.F.; Cantarutti, R.B.; Aguilar, M.A.G.; Bovi, M.L.A. 1998. Influência de diferentes relaçôes $\mathrm{NO}_{3}{ }^{-} / \mathrm{NH}_{4}^{+}$no crescimento de plântulas de pupunha (Bactris gasipaes H.B.K) em solução nutritiva. Agrotrópica, 10(1): 13-20.

Passos, L.P. 1996. Métodos analíticos e laboratoriais em fisiologia vegetal. Embrapa-CNPGL, Coronel Pacheco.

Pereira, E.G.; Siqueira, J.O.; Vale, F.R.; Moreira, F.M.S. 1996. Influência do nitrogênio mineral no crescimento e colonização micorrízica de mudas de árvores. Pesq. Agrop. Bras. 31(9): $653-$ 662.

Pimentel, C. 1998. Metabolismo de carbono na agricultura tropical. Seropédica, Rio de Janeiro.

Rosa, L.S.; Sá, T.D.A. Ohashi, S.T.; Barros, P.L.C.; Silva, A.J.V. 1997. Crescimento e sobrevivência de mudas de Rosewood (Aniba rosaeodora Ducke) oriundas de três procedências, em função de diferentes níveis de sombreamento, em condiçôes de viveiro. Boletim da Faculdade de Ciências Agrárias do Pará, 28: 37-62.

Sandoval, V.M.; Alcantar, G.; Tirado, J.L.T. 1995. Use of ammonium in nutrient solutions. J. Plant Nutr., 18: 1449-1457.

Van Beusichem, M.L.; Kirkby, E.A.; Baas, R. 1988. Influence of nitrate and ammonium nutrition and the uptake, assimilation, and distribution of nutrients in Ricinus communis. Plant Physiol., 86: 914-921.

Viégas, R.A.; Silveira, J.A.G. 2002. Activation of nitrate reductase of cashew leaf by exogenous nitrite. Tree Physiol., 14(1): 39-44.

Vitti, G.C.; Ferreira, A.C. (1997) Síntese de análises químicas em tecido vegetal. ESALQ - Departamento de Ciência do Solo.

Xiaoxin, L.; Chunsheng, H.; Delgado, J.A.; Yuming Z.; Zhiyun, O. 2007. Increased nitrogen use efficiencies as a key mitigation alternative to reduce nitrate leaching in north china plain. Agricultural Water Management, 89(2007): 137-147.

Recebido em 26/04/2007

Aceito em 17/08/2007 
